DOI: $10.15393 /$ j9.art.2019.6282

УДК 821.161.1.09“18”

А. Кавацца

Урбинский университет им. Карло Бо

(Урбино, Италия)

antonella.cavazza@uniurb.it

\title{
Ф. М. Достоевский и А. С. Хомяков: сравнение на расстоянии
}

Аннотация. Цель данной статьи заключается в выявлении точек соприкосновения между мировоззрением Ф. М. Достоевского и философскоисторическим наследием А. С. Хомякова. В текстах Достоевского имеется множество прямых и косвенных ссылок на работы идеолога славянофильства; писатель был знаком с его историко-философскими и богословскими сочинениями, а также с его стихотворениями. В частности, в статье анализируются и сравниваются два тесно связанных между собой вопроса в публицистике Достоевского и Хомякова: рассмотрение русской культуры в сравнении с европейской и противопоставление православия и католицизма. Отталкиваясь от двух центральных тем публицистики Достоевского - определение русской цивилизации по отношению к европейской и критику католицизма, - данное исследование, учитывая имеющиеся значительные сходства с произведениями Хомякова, стремится уточнить некоторые термины и стилистические приемы, с помощью которых эти идеи конкретизируются в публицистике Достоевского, особенно в «Дневнике писателя».

Ключевые слова: почва, народность, культура, просвещение, православие, католицизм, восточный вопрос, славянский вопрос

Об авторе: Кавацциа Антонелла - PhD, доцент славистики, Урбинский университет им. Карло Бо (Piazza Rinascimento, 7, г. Урбино, Италия, 61029) Дата поступления: 15.02.2019

Дата публикации: 18.10.2019

Для цитирования: Кавацца А. Ф. М. Достоевский и А. С. Хомяков: сравнение на расстоянии // Проблемы исторической поэтики. - 2019. T. 17. — № 4. - C. 123-148. DOI: 10.15393/j9.art.2019.6282

И дейные установки произведений Ф. М. Достоевского (особенно это касается его публицистики) в разной степени обнаруживают близость ко взглядам ранних славянофилов, в частности, А. С. Хомякова. Достоевский, в текстах которого имеется множество прямых и косвенных ссылок на работы идеолога славянофильства ${ }^{1}$, был знаком с его историко-философскими 
и богословскими сочинениями ${ }^{2}$. В русском литературоведении отражение историософских идей Хомякова в творческом наследии Достоевского рассмотрено в значительном количестве исследований (см.: [Осповат], [Бадалян], [Викторович], [Захаров, 2013]). Еще А. Л. Осповат, вслед за Г. М. Фридлендером и Л. В. Черепниным, отмечал «воздействие на Достоевского исторической концепции славянофилов, отразившееся в его показаниях на следствии по делу петрашевцев» [Осповат: 181]. Это говорит о серьезном творческом интересе молодого писателя к некоторым положениям раннего славянофильства уже в сороковых годах XIX в. В. А. Викторович полагает, что «под воздействием и как бы при участии Хомякова (вкупе с Григорьевым) формируется у Достоевского глобальная концепция истории европейской цивилизации» [Викторович: 146]. В настоящем исследовании рассматриваются два центральных вопроса публицистики Достоевского: определение русской цивилизации в сравнении с европейской и критика католицизма; делается попытка уточнить некоторые термины и стилистические методы, с помощью которых эти вопросы материализуются в публицистических работах Достоевского, особенно в «Дневнике писателя».

Выявлению точек соприкосновения между мировоззрением Достоевского и историософским наследием Хомякова посвящены два тематических блока, которые продемонстрируют не только близость, но и их возможные расхождения по вопросам взаимодействия русской и европейской культур, а также по отношению к католицизму и православию.

\section{Русская и европейская культура}

В статье «О возможности художественной школы» (1847), обличая чрезмерную зависимость России от европейской культуры, Хомяков анализирует источники этой зависимости и усматривает главную ее причину в отрыве от «родной почвы»:

«...я прибавлю только два-три примера, чтобы яснее показать, как наша школьническая подражательность (необходимое следствие отчуждения от своей родной почвы) убивает в нас ясность разума и даже изобретательность в делах самого простого быта». 
Важно отметить, что понятие «почва» используется Хомяковым в переносном смысле для обозначения одновременно корней русской культуры и всего, что ее характеризует. Образное значение этого слова проявляется в идеологеме «почва» впервые употребленной Достоевским в 1860 г. в программе создаваемого тогда журнала «Время»:

«Мы знаем теперь, что мы и не можем быть европейцами, что мы не в состоянии втиснуть себя в одну из западных форм жизни, выжитых и выработанных Европою из собственных своих национальных начал, нам чуждых и противоположных, точно так, как мы не могли бы носить чужое платье, сшитое не по нашей мерке. Мы убедились наконец, что мы тоже отдельная национальность, в высшей степени самобытная, и что наша задача - создать себе новую форму, нашу собственную, родную, взятую из почвы нашей, взятую из народного духа и из народных начал. Но на родную почву мы возвратились не побежденными. Мы не отказываемся от нашего прошедшего: мы сознаем и разумность его. Мы сознаем, что реформа раздвинула наш кругозор, что через нее мы осмыслили будущее значение наше в великой семье всех народов» (Д30; 18:36-37).

В «<Объявлении о подписке на журнал “Время” на 1861 год>» Достоевский использует те же понятия и термины, что и ранние славянофилы: помимо метафоры «почва» и образа «платья» ${ }^{5}$, соотносящегося с русскими обычаями, употребляются прилагательные «самобытный» и «народный». Образ одежды как символ национального самосознания подчеркивается в послании Хомякова к сербам:

«По-видимому, весь обычай состоит из мелочей, но он не мелочь. Что́ бы могло быть, например, важного в одежде? Не все ли равно, как человек одет и как сшиты лоскуты, которыми он прикрывается? Ведь это вещь вовсе мертвая и неспособная действовать на жизнь? Так и у нас толкуют, но вы этим толкам не верьте. Таково благородство души человеческой, что и мертвое получает от нее живое значение, в свою очередь действует на жизнь. Изменение одежды народной и предпочтение одежды западной происходят от злого источника, от презрения к своему и раболепства перед чужим» (358).

Мнение Хомякова о реформах Петра Великого, затронувших все сферы жизни общества (в том числе указ о ношении платья 
на западный манер), было довольно критическим. В частности, отрицательной была его оценка подхода к воспитанию детей в Петровскую эпоху:

«Если школьное учение находится в прямой противуположности с предшествующим и, так сказать, приготовительным воспитанием, оно не может приносить полной, ожидаемой от него пользы; отчасти оно даже делается вредным: вся душа человека, его мысли, его чувства раздвояются; исчезает всякая внутренняя цельность, всякая цельность жизненная; обессиленный ум не дает плода в знании, убитое чувство глохнет и засыхает; человек отрывается, так сказать, от почвы, на которой вырос, и становится пришельцем на своей собственной земле. Таково было действие переворота, совершенного Петром Первым. Ошибка извиняется, может быть, многими обстоятельствами его времени, но повторять такую ошибку беспрестанно было бы непростительно» («Об общественном воспитании в России» - 222).

Достоевский, в отличие от Хомякова, считал, что предпринятые Петром I преобразования, несмотря на недостатки, представляли собой в целом положительное явление. Петрово дело расширило мировоззрение русских, заставило их временно выйти за рамки своих границ, чтобы узнать Европу и вернуться затем на родную «почву» с новыми представлениями, которые в будущем позволили бы им породить «русскую идею» как синтез множества идей, усердно развиваемых Европой (см.: Д30; 18:35-37) 6 . В этой связи Достоевский видел необходимость в примирении идей западников и славянофилов, создав на этом единстве культурную программу журнала «Время», ставшую предпосылкой для идейного движения, которое впоследствии получило название почвенничество ${ }^{7}$.

В той же статье 1847 г., считая вредоносной зависимость русской культуры от Запада, подчиняющего себе Россию как в обыденной жизни, так и в сфере искусства и науки, Хомяков писал:

«...тот, кто оторвался от своего народа, тот создал кругом себя пустыню, как бы он ни был окружен множеством людей и как бы он ни считал себя членом общества» $(149-150)^{8}$. 
Прививаемая обществу западная культура породила плоды интеллектуального презрения по отношению ко всему исконно русскому, и это, по мнению Хомякова, было причиной раздвоения русского общества ${ }^{9}$. Русское просвещение - тот родной источник, «которого прозрачная глубина (создание чистого и раннего христианства) одна может исцелить глубокую рану» внутреннего раздвоения русского общества (103). В этой связи, по мнению Хомякова, получение новой энергии за счет объединения с западной культурой было нежелательным, поскольку лежащие в ее основе начала были полностью чуждыми русской земле и не могли привиться никоим образом. Россия должна была осознать свою болезнь и лечить ее, с одной стороны, возвращаясь к своим христианским корням, а с другой - возобновляя прямую связь с русским народом и своими традициями:

«...ибо только в живом общении с народом выходит человек из мертвенного одиночества эгоистического существования и получает значение живого органа в великом организме; только при нем может всякая здравая мысль и всякое теплое чувство, возникшее в каждом отдельном лице, сделаться достоянием общим и получить влияние и важность, не изъявляя и не имея притязаний на важность и влияние; только при нем возможно то просвещение, к которому Запад стремится безнадежно и которого достигнуть не может вследствие своего внутреннего раздвоения» $(158)^{10}$.

Достоевский считал, что связь с народом была жизненно важной для новой Руси, характеризуя ее во введении к циклу «Ряд статей о русской литературе» 1861 г. следующим образом:

«Наша новая Русь поняла, что один только есть цемент, одна связь, одна почва, на которой все сойдется и примирится, - это всеобщее духовное примирение, начало которому лежит в образовании. Эта новая Русь уже засвидетельствовала себя явлениями органическими и цельными, а не неудавшимися копиями и пересадками, как вы думаете» (Д30; 18:50).

Наряду с термином «почва» заслуживает внимания определение «цельный», перекликающееся с понятием «цельность», характерным для философско-религиозных взглядов Хомякова 
(«исчезает всякая внутренняя цельность, всякая цельность жизненная»).

В этой статье Достоевский называет русскую нацию «необыкновенным явлением в истории всего человечества»:

«Характер русского народа до того не похож на характеры всех современных европейских народов, что европейцы до сих пор не понимают его и понимают в нем все обратно» (Д30; 18:54).

Эти взгляды Достоевского в большей степени перекликаются с ироническими замечаниями и парадоксальными выводами, сделанными Хомяковым в статьях «Мнение иностранцев о России» (1845) и «Мнение русских об иностранцах» (1846). Например, отмечая неспособность европейцев понять Россию, Достоевский писал:

«Скорее изобретется perpetuum mobile или жизненный эликсир, чем постигнется Западом русская истина, русский дух, характер и его направление. В этом отношении даже Луна теперь исследована гораздо подробнее, чем Россия. По крайней мере, положительно известно, что там никто не живет; а про Россию знают, что в ней живут люди и даже русские люди, но какие люди? Это до сих пор загадка, хотя, впрочем, европейцы и уверены, что они нас давно постигли» (Д30; 18:41).

Достоевский приводит придуманные реплики воображаемых иностранцев, используемые им как провокация, чтобы разбудить читателя и вместе с тем пробудить в нем процесс национального самосознания:

«- Но позвольте, - скажут нам, - что же такое ваша-то национальность? Что же такое вы сами, русские? Вот вы хвалитесь, что мы вас не знаем; но знаете ли вы-то себя?» (Д30; 18:51).

Для писателя процесс самосознания неотделим от чувства самоуважения; они могут развиваться только благодаря знанию русской истории (см. об этом: [Сохряков: 15-16]). В этом также был глубоко убежден Хомяков, автор «Записок о Всемирной истории» ${ }^{11}$.

Мнения Достоевского и Хомякова по поводу качеств, которыми должна была обладать русская культура в противовес европейской, полностью совпадают. В 1860 г. в «<Объявлении 
о подписке... >» Достоевский утверждал: «Мы не Европа, и у нас не будет и не должно быть победителей и побежденных» (Д30; 18:36). Эти слова отсылают к статье Хомякова «О возможности художественной школы», в которой он отмечал присутствие на Западе народов «завоеванных» и «завоевательных», где первые «сильнее “впитывают” в себя чужую культуру - культуру завоевателей» [Цыплаков, Желябовский: 64]:

«Началом Запада была двойственность в жизни народной (завоеванные и завоеватели) и двойственность в понятии духовном: ибо односторонность римского определения единства в покорности (следовательно, единства внешнего) вызывала необходимо и вызвала отрицательную односторонность свободы в разномыслии (следовательно, внешней, ибо свобода разумная едина)» (143-144).

В одном из писем А. Н. Майкову от 21-22 марта (2-3 апреля) 1868 г. Достоевский заявлял о согласии с толкованием истории Западной Европы, предложенном славянофилами. По этому поводу писатель отмечает «любовное, а не завоевательное начало <русского> государства», определяя его «величайшей мыслью, на которой много созиждется» (Д30; 28,280). Аналогичная мысль выражена Хомяковым в статье о И. В. Киреевском:

«Можно бы доказать, что внутренняя раздвоенность Западнаго міра была усилена Германскимъ завоеваніемъ не только вслъдствіе отношеній завоеванныхъ къ завоевателямъ, но еще и всльдствіе грубой безнравственности побъдительнаго племени» ${ }^{12}$.

Оценка Достоевского, тем не менее, только частично совпадала с восторженным мнением о славянофилах поэта, критика, переводчика, одного из активных сотрудников «Времени» Ап. Григорьева и детально для читателей журнала не обосновывалась. Положительное мнение Григорьева о ранних славянофилах, действительно, не отражало позицию всей редакции «Времени». Кроме того, как подчеркивал сам Достоевский в примечании к воспоминаниям Н. Н. Страхова о Григорьеве (Эпоха. 1864. № 9. С. 1-55), это мнение расходилось с далекими от одобрительных общественными суждениями о Хомякове и Киреевском ${ }^{13}$. В начале 1860-х гг. 
Достоевский открыто дистанцировался от славянофилов. Так, со страниц журнала «Время» (1861. № 11) в статье «Последние литературные явления. Газета “День”, Достоевский упрекал славянофилов в чрезмерном идеализме и отсутствии чувства реальности. В частности, он считал несправедливым обвинение, предъявленное всей русской литературе, в подражании западным образцам и ксенофилии. Комментируя первый номер газеты «День», содержащий статьи К. Аксакова и Хомякова, Достоевский со страниц «Времени» выказывал им свое порицание по этому поводу: «Что же вы свысока-то на нее смотрите, как козявку ее разбираете? Да ведь вы сами литераторы, господа славянофилы» (Д30; 19:63) ${ }^{14}$.

Не исключено, что, критикуя их статьи, редактор журнала «Время» имел в виду и некоторые высказывания Хомякова о современной литературе. Последний, в частности, с высокомерием высказывался о «Бедных людях». Полностью игнорируя успех, который этот роман, опубликованный в 1846 г., имел у современников, Хомяков оценил его следующим образом:

«Восстановление наших частных умственных сил зависит вполне от живого соединения с стародавнею и все-таки нам современною русскою жизнию, и это соединение возможно только посредством искренней любви. Иные твердят о своих патриотических чувствах, а “людей в Киеве ничем зовут”, как царь Калин в сказке, или ругаются над неученою Русью, как чиновник в повести Достоевского, высказавшего (не знаю, сознательно или нет) в этом презрении Девушкина к мужику и бабе страшное оправдание его собственных страданий» (156).

Эта, без сомнений, поспешная и недальновидная оценка Хомякова отражала эстетические представления первых славянофилов, испытывавших ностальгию по античному эпосу и критиковавших европейский роман. Со своей стороны, автор «Бедных людей» не мог поддержать подобные позиции. Особенно разочаровывало Достоевского сдержанное отношение ранних славянофилов к Пушкину (см.: [Житкова]), которого писатель считал уникальным и пророческим явлением русского духа на заре национального самосознания, спустя целое столетие со времени петровской реформы (Д30; 26:136).

Расхождение взглядов Достоевского и Хомякова на литературу в целом не снизило интереса писателя к философско- 
исторической системе взглядов идеолога славянофильства, между которыми можно обнаружить еще одну значимую точку соприкосновения: глубоко связанное с языком и народом понятие «национальности». Достоевский считал очень важным изучение русского языка на родине, а не за границей, например, во Франции, куда переезжали многие русские, чтобы подготовить своих детей, например, к карьере дипломата. Привлекая внимания читателя к бедному, почти бессмысленному культурному образованию русских молодых людей, выросших за границей, Достоевский писал:

«Причина - русский язык, то есть недостаток русского, отечественного языка от воспитания за границей, с гувернантками и боннами иностранками. Это у нас и всегда водилось, и прежде, то есть недостаток этот, но никогда как теперь, когда столько херувимчиков взрастет за границей» (Д30; 25:140).

Как отмечала Н. А. Тарасова, сравнивая публикацию «Дневника писателя» в 30-томном полном собрании сочинений с печатным изданием 1878 г. и наборной рукописью, относящиеся к языку термины «русский» и «отечественный» написаны в рукописи с заглавной буквы, в то время как «французский» - со строчной (см.: [Тарасова: 222, 224]) ${ }^{15}$. Именно использование заглавной буквы в данном случае подчеркивало роль, которую отводил писатель русскому языку в обучении молодых соотечественников, разоблачая при этом ограниченность подготовки так называемого «европейского русского», по поводу которого он писал:

«Не имея же своего языка, он естественно схватывает обрывки мыслей и чувств всех наций, ум его, так сказать, сбалтывается еще смолоду в какую-то бурду, из него выходит международный межеумок с коротенькими, недоконченными идейками, с тупою прямолинейностью суждения» (Д30; 25:141).

Следовательно, в понимании Достоевского только тесный контакт с языком, религиозной верой и ежедневной жизнью своего народа мог сформировать черты подлинной национальной культуры. Это убеждение совпадало по существу с мнением, выраженным Хомяковым в статье «Разговор в Подмосковной» 1856 г., в которой один из основоположников 
движения славянофилов излагал в форме диалога свое понимание народности. В этой статье в драматической форме Хомяков устами своего героя И. А. Тульнева утверждал:

«Итак, значение имеет не происхождение, а язык. Что же? Много говорим мы, много думаем мы по-русски? Есть чем похвалиться. Да и слово-то наше разве русское вполне? Ведь слово не в лексиконе одном (а и тот у нас оскудел) и не в грамматике (которая, впрочем, у нас построена Бог весть как и для какого языка); оно в самом отношении мысли и чувства к звукам, служащим выражением для них. Больше того: слово народное не в одних словах, а во всех народных обычаях, сочувствиях, обрядах, во всем быте народа. Язык, конечно, отчасти не позволит нам вовсе оторваться от родины и быть совершенно похожими на наших парижских знакомых; но, право, недалеко ушли мы от них» $(252)^{16}$.

О необходимости для творчества быть погруженным в родную среду и быт свидетельствует постоянное желание Достоевского возвратиться в Россию, которое он испытывал во время четырехлетнего пребывания в Европе в конце 1860-х годов. Это время было омрачено щемящей ностальгией по родной земле и русскому языку ${ }^{17}$.

\section{Катодицизм и православие}

Сравнение России и Европы было тесно связано у Достоевского с конфессиональной антиномией «православие-католицизм». Основные положения, критикуемые писателем, были взяты из трех статей теологического характера Хомякова, опубликованных изначально на французском языке:

«Quelques mots par un chrétien orthodoxe sur les communions occidentales à l'occasion d'une brochure de M. Laurentie» («Несколько слов православного христианина о западных вероисповеданиях по поводу брошюры г. Лоранси») (Париж, 1853);

«Quelques mots par un chrétien orthodoxe sur les communions occidentales à l'occasion d'un Mandement de l'Archevêque de Paris (Mgr. Sibour)» («Несколько слов православного христианина о западных общинах по случаю послания архиепископа парижского») (1855);

«Encore quelques mots d'un chrétien orthodoxe sur les confessions occidentales à l'occasion de plusieurs publications religieuses, latines 
et protestantes» («Еще несколько слов православного христианина о западных вероисповеданиях, по поводу разных сочинений латинских и протестантских о предметах веры») (Лейпциг, 1858).

Рассматривая западные христианские вероисповедания, идеолог славянофильства заключает, что католицизм пожертвовал свободой ради единства, а протестантизм - единством ради свободы и только православию удалось сохранить эти начала, объединив их. Разделяя мнение Хомякова относительно причин, которые исторически обусловили разделение Церкви на Восточную и Западную, Достоевский отмечал, что рационализм и формализм, лежащие в основе склада ума древнеримской цивилизации, послужили фундаментом для «католической идеи», предвещающей новые идеологии, которые искажали суть христианства. Кратко изложив сущность восточного вопроса в «Дневнике писателя» 1877 г. в статье «Толки о мире. “Константинополь должен быть наш” - возможно ли это? Разные мнения», Достоевский установил связь между судьбами православия и миссией России в разрешении восточного вопроса. Это было противоположно мнению, поддерживаемому католицизмом, который писатель клеймил следующим образом:

«Римское католичество, продавшее давно уже Христа за земное владение, заставившее отвернуться от себя человечество и бывшее таким образом главнейшей причиной матерьялизма и атеизма Европы, это католичество естественно породило в Европе и социализм. Ибо социализм имеет задачей разрешение судеб человечества уже не по Христу, а вне Бога и вне Христа, и должен был зародиться в Европе естественно, взамен упадшего христианского в ней начала, по мере извращения и утраты его в самой церкви католической. Утраченный образ Христа сохранился во всем свете чистоты своей в православии. С Востока и пронесется новое слово миру навстречу грядущему социализму, которое, может, вновь спасет европейское человечество. Вот назначение Востока, вот в чем для России заключается Восточный вопрос» (Д30; 26:85).

В статье «Три идеи», открывающей «Дневник писателя» 1877 г., католической идее и протестантизму, который в понимании Достоевского был тесно связан с католицизмом 
и зависел от него как «протестантское» и негативное вероисповедание ${ }^{18}$, писатель противопоставляет «славянскую идею». Эта идея сильно напоминает теорию панславизма Хомякова, которая в этой статье не упоминается. Однако суть сформулированной Достоевским идеи восходит к славянофильскому манифесту Хомякова «К сербам. Послание из Москвы». Этот текст, по всей видимости, был полностью проигнорирован писателем, который представлял читателям славянскую идею как тесно связанную с восточным вопросом в соответствии с его толкованием в 1870-х гг.:

«А между тем на Востоке действительно загорелась и засияла небывалым и неслыханным еще светом третья мировая идея идея славянская, идея нарождающаяся, - может быть, третья грядущая возможность разрешения судеб человеческих и Европы. Всем ясно теперь, что с разрешением Восточного вопроса вдвинется в человечество новый элемент, новая стихия, которая лежала до сих пор пассивно и косно и которая, во всяком случае и наименее говоря, не может не повлиять на мировые судьбы чрезвычайно сильно и решительно. Что это за идея, что несет с собою единение славян? - всё это еще слишком неопределенно, но что действительно что-то должно быть внесено и сказано новое, - в этом почти уже никто не сомневается» (Д30; 25:9).

Следует добавить, что с самого начала русско-турецкой войны (1877-1878) автор «Дневника писателя» был твердо убежден в том, что восточный вопрос является также и славянским вопросом (см.: [Новикова: 45-46]). В «Письме к приятелю-иностранцу. Перед началом восточной войны» (1854) Хомяков также подчеркивал связь между этими вопросами. Он написал:

«Что бы ни случилось, но Провидьніе, очевидно, отмбтило наше время, какъ время событій и переворотовъ въ судьбахъ міра. Отнынъ воздвигаются два великія начала: одно - начало Русское, или скорье Славянское, начало дъйствительнаго (реальнаго) братства, братства крови и духа; другое, еще несравненновысшее, начало Церкви. Только под ея благодътельнымъ крыломъ и могло сохраняться начало братства среди міра мятежей и раздоровъ...» ${ }^{19}$.

В славянской идее Достоевского Россия, несомненно, играла центральную роль. В статье «Одно совсем особое словцо 
о славянах, которое мне давно хотелось сказать» писатель утверждал, что Россия привлечет к себе славян, которые «воротятся в родное гнездо» (Д30; 26:81). Достоевский метафорически называет Россию «гнездом», образ которого возникает в стихотворениях Хомякова «Орел» и «Вставайте! оковы распались» ${ }^{20}$. Формулируя освободительную миссию славянских народов, Достоевский выражал пожелание, не лишенное некоторых критических замечаний в их адрес, которые отсутствовали в панславизме первых славянофилов ${ }^{21}:$ «...вознести наконец всех малых сих до себя и до понятия ими материнского ее призвания - вот цель России, вот и выгоды ее, если хотите» (Д30; 26:81), где определение «малых сих», касающееся славян и восходящее к Евангелию, перекликается с обращением «меньшие братья», используемым Хомяковым в отношении славян в стихотворении «Кремлевская заутреня на Пасху» $(1850)^{22}$. В соответствии со взглядами первых славянофилов Достоевский считал, что православию отведена решающая роль в возрождении русского общества, в отличие от католицизма и протестантизма.

В том, что Россия была верным хранителем православия с периода Средневековья, Достоевский усматривал не только заслугу, но и ответственность перед другими православными народами, как славянами, так и греками, которых она должна была защитить, а в будущем возглавить. Славянский вопрос вкупе с религиозным ранее уже рассматривался с особым вниманием в «Послании к сербам». Панславизм Достоевского, в отличие от панславизма Хомякова, имел более выраженную религиозную основу. Например, в статье «Утопическое понимание истории» автор «Дневника писателя» рассматривает в основном не политические и юридические аспекты будущего единства всех славян, а сохраненные на Востоке ${ }^{23}$ «подлинные христианские принципы». Осознавая риск быть принятым за утописта, он излагал миссию России в отношении к славянам и, в целом, к европейцам, следующим образом:

«Нет, это будет настоящее воздвижение Христовой истины, сохраняющейся на Востоке, настоящее новое воздвижение креста Христова и окончательное слово православия, во главе которого давно уже стоит Россия» (Д30; 23:50). 
Следовательно, сравнение с Европой для Достоевского, равно и для Хомякова, выражается посредством сопоставления православия и католицизма. Последний в работе «Церковь одна» имплицитно обвинил Римскую церковь в ереси ${ }^{24}$. Достоевский вышел за рамки экклезиологии, установив связи в политической и общественной среде между католицизмом и социализмом. С точки зрения писателя, рационализм и формализм с течением времени «высушили» католическую веру, которую в подготовительных материалах к «Дневнику писателя» за 1876 г. он описывал следующим образом:

«Католичество - страшная окаменелость, и как раз в наш век ему надо было окаменеть. Эта страшная вера была главною гибелью всей Европы, 3-е дьяволово искушение. Энциклопедисты. Наука. Но наука пока теория. Теперь вновь гонение на католичество. До сих пор оно блудодействовало с царем, теперь с демосом. Рамон <?> Болье <? >» (Д30; 22:164).

В этой связи важно отметить, что Н. А. Тарасовой удалось уточнить прочтение последних слов, данное в 30-томном собрании сочинений как предположительное: «Романъ Бъсы» [Тарасова: 57]. Это позволило связать данную запись с отрывком из романа «Бесы», в котором Шатов вспоминает критику католицизма со стороны Ставрогина ${ }^{25}$.

С начала 1860-х гг. со страниц журналов «Время» и «Эпоха», а впоследствии журнала «Гражданин» Достоевский как публицист со вниманием следил за сложными отношениями между папой Пием IX и европейскими правителями. В статье «Сила мертвая и силы грядущие», опубликованной в мартовском «Дневнике писателя» за 1876 г., комментируя догмат о папской непогрешимости, провозглашенный Первым Ватиканским собором в 1870 г., Достоевский обвинял католичество в том, что оно «блудодействовало лишь с сильными земли», «раз, когда надо было, оно, не задумавшись, продало Христа за земное владение» (Д30; 22:88). Кроме того, он добавлял:

«Провозгласив как догмат, “что христианство на земле удержаться не может без земного владения папы”, оно тем самым провозгласило Христа нового, на прежнего не похожего, прельстившегося 
на третье дьяволово искушение, на царства земные: “Всё сие отдам тебе, поклонися мне!” (Д30; 22:88).

Третье искушение, которому подвергся Христос в пустыне, заключалось в обещании стать властелином мира в обмен на подчинение сатане. По мнению Достоевского, папа уже давно поддался этому искушению, присвоив себе как духовную власть, так и достоинство земного властителя, от которых он не был намерен отказываться и в будущем (Д30; 25:160).

В отношении к папству можно наблюдать полное соответствие взглядов Достоевского и Хомякова. В статье «Quelques mots <...> d'une brochure de M. Laurentie» власть папы определялась Хомяковым как «исключительно внешняя власть», в то время как сам папа назывался «невольным оракулом, статуей из плоти и костей, приводимой в движение невидимыми устройствами» (перевод мой. - A. К.) ${ }^{26}$. По отношению к папе римскому и Римской церкви Хомяков делал следующие заключения:

«Полностью внешний и, следовательно, рациональный закон заменил моральный и живой закон - единственный, который не подчиняется рационализму, поскольку распространяется не только на разум, но и на все существо» ${ }^{27}$.

Искушения, описанные в Евангелии, выражаются Достоевским в аллегорической форме в «Легенде о Великом Инквизиторе» ${ }^{28}$, так как католицизм является для Достоевского существенным вопросом и встречается не только в публицистических трудах, но и в его романах. Согласно Г. Загребельскому, Великий Инквизитор воплощал собой католицизм, который потерял веру во Христа, будучи слишком занятым материальным благосостоянием своей паствы, посвятив себя исключительно земной миссии, в которой христианское послание было извращено политикой и «сведено к искусству правления или христианской экономики» ${ }^{29}$.

Следовательно, «Легенда о Великом Инквизиторе» образно передавала в литературной форме некоторые критические замечания в адрес Римской церкви, сформулированные в свое время Хомяковым в статье «Церковь одна» и ранее представленные Достоевским на фоне исторических и социальных 
событий второй половины XIX в. более жестко. Достоевский дистанцировался от оценок Хомякова как литературоведа, хотя полностью принял его оценку Римской церкви: он не только поддержал обвинение папы римского в ереси, но и неоднократно сравнивал папу с антихристом.

\section{$* * *$}

Анализ рассмотренных выше вопросов позволил выявить важные точки соприкосновения между публицистикой Хомякова и Достоевского. Они состоят в дальнейшем развитии Достоевским историко-философских и экклезиологических воззрений Хомякова. Оба автора развивают такие ключевые понятия, как «почва», «самобытное», «народное», «цельный» и «православие» с помощью которых характеризуется русская культура в сравнении с европейской. Несмотря на имеющиеся расхождения, их концепции русского просвещения, в основном, совпадают. После смерти Хомякова в 1860 г. Достоевский продолжил развитие определения новой культуры, основанной на православных христианских началах, и критики западной культуры в католическом и протестантском вероисповеданиях, которые в прошлом оказывали и продолжают оказывать значительное влияние на культуру Запада и - косвенно - на русскую культуру.

В прошлом Запад был, по выражению Хомякова, «страной святых чудес» (стихотворение «Мечта»); таковым он перестал являться в XIX в. ${ }^{30}$ В своем творчестве Достоевский не раз прибегал к аллюзии на это стихотворение Хомякова. Например, метафорическое определение Запада («страна святых чудес») использовано в «Зимних заметках о летних впечатлениях» (Д30; 5:47, 51). Также эта метафора неоднократно встречается в главах «Дневника писателя» за 1876 (Д30; 21:30), 1877 (Д30; 25:198) и 1881 гг. (Д30; 27:36) и записной тетради 18761877 гг. (Д30; 24:219) $)^{31}$.

Процесс национального самосознания в России был начат славянофилами в их спорах с западниками. Этот процесс во второй половине XIX в. получил развитие благодаря литературной и гражданской деятельности Достоевского, пытавшегося соединить идеи обоих движений. Тем не менее, в новом 
историческом контексте, сложившемся в России при Александре II, великий русский писатель счел необходимым отказаться от некоторых взглядов ранних славянофилов, назвав их в начале 1870-х гг. «барской затеей» ${ }^{32}$. Несмотря на подобные замечания, указывающие на разницу социального положения своего и Хомякова, разночинец Достоевский ${ }^{33}$ в действительности разделял многие взгляды ранних славянофилов и развивал их как в публицистике, так и в художественном творчестве. В частности, идеи о «русском народе», «национальности» и «православной вере» совпадали в культурных программах славянофильства и почвенничества. И Хомяков, и Достоевский были убеждены, что подлинная культура не может основываться только на научном знании и должна развивать моральные принципы, берущие начало в православной вере.

Вслед за Хомяковым Достоевский продолжил обличение негативного влияния рационализма и католицизма на западную культуру, находя связь между папством и некоторыми революционными политическими движениями, действовавшими в Европе и в России во второй половине XIX в. В этом он видел «несознательность» Европы, «разрушить путы» которой Россия смогла бы в будущем, став выразителем «той громадной идеи», способной изменить мир и исходящей от русских с Востока, а именно - от православия (Д30; 11:167). Призыв Хомякова к Востоку в заключительной строке стихотворения «Мечта» («Проснися, дремлющий Восток!») соотносится с идеями Достоевского об исторической миссии России, состоящей в полном нравственном обновлении мира. В основе этого, согласно мировоззрению великого писателя, лежит Христос, но «русский», а не «римский» Христос, ставший «Кесарем» ${ }^{34}$.

\section{Примечания}

1 См. сводный указатель имен: Достоевский Ф. М. Полн. собр. соч.: в 30 т. Л.: Наука, 1990. Т. 30. Кн. 2. С. 364. Далее при цитировании используется сокращение Д30, с указанием тома, книги (нижний индекс) и страницы в круглых скобках.

2 В библиотеке Достоевского, кроме собрания сочинений Хомякова 1879-1882 гг., был и первый том 4-томного собрания сочинений Хомякова: Хомяков А. С. Полн. собр. соч.: в 4 т. М.: Тип. П. Бахметева, 1861. T. 1.722 с. (см.: [Гроссман: 45], [Библиотека Ф. М. Достоевского: 146]). 
3 Хомяков А. С. О старом и новом. Статьи и очерки. М.: Современник, 1988. С. 146-147. Далее ссылки на это издание приводятся в тексте статьи с указанием страницы в круглых скобках.

4 Подробнее об идеологеме «почва» и почвенничестве в русской литературе см.: [Захаров, 2012a].

5 О роли метафоры в философско-публицистическом творчестве Хомякова см.: [Сафонова, Халикова].

6 Оценка Достоевским реформы Петра Первого более близка к оценке В. Г. Белинского (см.: Белинский В. Г. Литературные мечтания // Белинский В. Г. Полн. собр. соч.: в 13 т. М.: Изд-во АН СССР, 1953. Т. 1. С. 38-39), чем Хомякова.

7 Сам этот термин никогда не использовался Достоевским (см.: [Захаров, 2012a: 14]).

8 Отголоски этих рассуждений можно уловить в конце романа «Бесы», в письме Ставрогина к Даше: «Вашъ братъ говорилъ мнъ что тотъ кто теряетъ связи съ своею землей, тотъ теряетъ и боговъ своихъ, то-есть всъ свои цъли» (Достоевский Ф. М. Полн. собр. соч.: Канонические тексты. Петрозаводск: Изд-во ПетрГУ, 2012. Т. 9. С. 632).

9 Эту мысль Хомяков выразил в статье «Мнение иностранцев о России» (96).

10 В этой же статье, «О возможности русской художественной школы», Хомяков отмечал: «Тонкие, невидимые струны, связывающие душу русского человека с его землею и народом, не подлежат рассудочному анализу» (158).

11 Отражение этих взглядов см., напр., в работах Хомякова: «Семирамида», «Несколько слов о философическом письме (напечатанном в 15 книжке “Телескопа”) (Письмо к г-же Н.)», «О старом и новом», «Замечания на статью г. Соловьева “Шлецер и антиисторическое направление”»; <«Предисловие к “Русской беседе”»>. (Хомяков А. С. Сочинения: в 2 т. М., 1994. Т. 1: Работы по историософии. С. 34, 455, 470, 516-517, 531). «Записки о Всемирной истории» - это историко-философский труд, который не был озаглавлен автором. Вслед за Н. В. Гоголем друзья Хомякова называли это произведение «Семирамидой» [Кошелев, Серебренников, Чернов: 537-539]. Впервые часть «Семирамиды» была напечатана в журнале «Русская Беседа» с названием «Отрывки из Записок А. С. Хомякова о Всемирной истории» (1860. Т. 2. «Науки». С. 101-178).

12 Хомяков А. С. По поводу статьи И. В. Киреевского «О характере просвещения Европы и о его отношении к просвещению России // Хомяков А. С. Полн. собр. соч.: в 8 т. М.: Университетская тип., 1900. T. 1. С. 197-260.

13 Достоевский вспоминал, что редакция журнала «Время» хотела бы, чтобы А. А. Григорьев аргументировал свои взгляды относительно славянофилов: «...на этот вопрос редактора “Времени” Ап. Григорьев 
так и не ответил: в его критике есть восторженные оценки, но так и не последовало объяснение, в чем состоит глубина философии славянофилов» [Захаров, 2013: 236].

14 В первом номере газета «День» 1861 г. вышли следующие статьи, написанные соответственно А. С. Хомяковым и К. С. Аксаковым: «Об общественном воспитании в России» и «Наша литература». Статья Хомякова «Об общественном воспитании в России» (1850) была опубликована с многочисленными цензурными изъятиями; полная версия впервые появилась в его Собрании сочинений 1900 года (Хомяковъ А. С. Полн. собр. соч.: въ 8 т. М., 1900. Т. 1. С. 351-374), где была ошибочна отнесена к 1858 г. (см. об этом: [Егоров: 437]).

15 В. Н. Захаров подчеркивает значимость заглавных букв в романе «Бесы» Достоевского [Захаров, 2012b].

16 Подробнее о понимании народности Хомяковым, выраженном в статье «Разговор в Подмосковной» см.: [Бадалян: 110]. Размышления о языке встречаются также в «Послании Хомякова к сербам» (352) и в «Речь в заседании 28 апреля 1860 года» (Хомяковъ А. С. Полн. собр. соч.: въ 8 т. М., 1900. Т. 3. С. 452). О понимании Хомяковым языка как живого организма см.: [Грыжанкова: 50].

17 Ностальгия по России сопровождала Достоевского в течение всего путешествия за границу, в которое он, чтобы скрыться от кредиторов, отправился сразу после свадьбы с Анной Григорьевной Сниткиной. О тоске по родине он сообщает в письме из Милана к А. Н. Майкову от 26 октября (7 ноября) 1868 г.: «Письма Ваши меня обрадовали и ободрили, потому что нравственное состояние мое очень плохо. И во-первых, работа меня измучила и истощила. Вот уж год я пишу по 3 1 1/2 листа каждый месяц - это тяжело. Кроме того, - нет русской жизни, нет впечатлений русских кругом, а для работы моей это было всегда необходимо» (Д30; 28, $: 320)$. О местах, в которых останавливался Достоевский с 1867 по 1871 г., см.: [Supino].

18 Мнение Достоевского по этому вопросу совпадает с мнением Хомякова, который полагал, что протестанты были не кем иным, как «продолжателями доктрины Рима, лишь изменившими ее применение» (перевод мой. - A. К., в ориг.: "les continuateurs de la doctrine romaine, dont ils ont seulement changé l'application”). См.: Khomiakoff A. S. L'Eglise latine et le protestantisme au point de vue de l'Eglise d'Oriente. B. Benda, Libraire-Éditeur, Lausanne \& Vevey, 1872. P. 40.

19 Хомяковъ А. С. Полн. собр. соч.: въ 8 т. М., 1900. Т. 3. С. 190-191.

20 См. примечания к статье «Одно совсем особое словцо...»: (Д30; 26:399). В России стихотворение «Орел» было опубликовано в журнале «Парус» от 3 января 1859 г. под названием «Орел славянский»; «Вставайте! оковы распались» - в 1861 г. в издании «Русская потаенная литература XIX столетия. Отдел первый: Стихотворения. Часть 1», Лондон, 1861 (см.: Хомяков А. С. Стихотворения и драмы. Л.: Сов. писатель, 1969. С. 100-101, 133-134, 554-555). В библиотеке Достоевского имелся 
сборник стихотворений Хомякова, изданный в Москве в 1861 г. (см.: [Библиотека Ф. М. Достоевского: 98]).

21 В ориг:: «Un documento di altro genere, destinato ad altri fini, e caratterizzante da un altro punto di vista i rapporti degli slavofili con il panslavismo, nel periodo di transizione 1853-<18 $>61$, è invece la famosa Lettera ai Serbi [Pis'mo k Serbam] (1860), scritta da Chomjakov e firmata da K. e I. Aksakov, A. Košelev, J. Samarin nonché da altri slavofili e simpatizzanti dello slavofilismo. Non vi è in essa parola di 'guerre sante', future federazioni slave e - Dio ne guardi - di tutela russa sulla Slavia; la sua sostanza consiste invece in una serie di consigli che gli esperti "fratelli anziani" sentivano il bisogno di dare al giovane popolo slavo, da poco libero. La Lettera ai Serbi fu insomma un tentativo di adattare la dottrina slavofila alla situazione degli Slavi meridionali, un tentativo di creare tra essi un movimento di pensiero affine a quelli che erano gli ideali dellautore della Lettera. Essa rappresentò dunque una manifestazione non tanto di panslavismo stricto sensu (quantunque l'ispirazione panslavistica non potesse esservi messa in dubbio), quanto di slavofilismo nel senso letterale, etimologico della parola» («Документом другого рода, имеющим иное предназначение и характеризующим с другой точки зрения отношения славянофилов с панславизмом в переходный период 1853-1861 гг., является известное "Послание к Сербам" (1860), написанное Хомяковым и подписанное К. и И. Аксаковыми, А. Кошелевым, Ю. Самариным, а также другими славянофилами и их сторонниками. В нем нет ни одного слова о “святых войнах" и будущих славянских федерациях и - Боже помилуй! - о русской опеке над Славией; по сути оно содержит ряд советов, которые опытные "старшие братья" хотели дать недавно освободившемуся молодому славянскому народу. “Послание к Сербам" было, скорее, попыткой приспособления идеологии славянофилов к ситуации южных Славян, попыткой создать среди них идейное движение, подобное идеалам авторов “Послания". Как таковое, оно представлялось поэтому не проявлением панславизмa stricto sensu (хотя панславистский дух этого послания не вызывал сомнений), а проявлением славянофильства в буквальном, этимологическом смысле этого слова») (перевод мой. - A. K.) [Walicki: 491].

22 См. примечания к статье «Одно совсем особое словцо....»: (Д30; 26:399-400).

23 Славянофильская пропаганда считала греков «врагами славян» и «примером духовной гордости». Достоевский разделял это мнение, хотя, в отличие от подписавшихся под ставшим панславянским манифестом «К сербам. Послание из Москвы», считал, что решение национального вопроса не может обойти постановления Константинопольского собора 1872 г., объявившего болгар схизматиками. Разделяя это представление о греках, он тем не менее считал, что поставив национальный вопрос выше собственно церковного, болгары «исказили» христианство и к православию отнеслись как к «второстепенной вещи» (см. примечания к статье «Утопическое понимание истории» из «Дневника писателя» 1876 г. - Д30; 23:377-378). 
24 По этому поводу Хомяков писал: «Поэтому гордость разума и незаконной власти, присвоившая себе в противность приговору всей Церкви (высказанному на Соборе Халкидонском) право прибавить свои частные объяснения и человеческую догадку к Символу НикеоКонстантинопольскому, уже есть само по себе нарушение святости и неприкосновенности Церкви. Так как самая гордость отдельных церквей, осмелившихся изменить Символ всей Церкви без согласия братий своих, была внушена не Духом любви и была преступлением перед Богом и святой Церковью; точно также и их слепая мудрость, не постигавшая тайны Божией, была искажением веры» (см. текст статьи «Церковь одна» А. С. Хомякова в: [Cavazza: 27]).

О католицизме герой Достоевского говорил: «...вы вЂровали что римскій католицизмъ уже не есть христіанство; вы утверждали что Римъ провозгласиль Христа поддавшагося на третье дьяволово искушеніе, и что, возвъстивъ всему свъту что Христосъ безъ царства земнаго на земль устоять не можетъ, католичество тьмъ самымъ провозгласило антихриста и тъмъ погубило весь западный міръ. Вы именно указывали что если мучается Франція, то единственно по винъ католичества, ибо отвергла смраднаго бога римскаго, а новаго не сыскала. Вотъ что̀ вы тогда могли говорить! Я помню наши разговоры» (Достоевский Ф. М. Полн. собр. соч.: Канонические тексты. Т. 9. С. 239).

26 В ориг.: «С’était un oracle involontaire, une statue de chiar et d'os mue par des ressorts invisibles» (Khomiakoff A. S. L'Eglise latine et le protestantisme au point de vue de l'Eglise d'Oriente. P. 38).

27 В ориг.: «Une loi tout extérieure, et par conséquent rationelle, avait remplacé la loi morale et vivante, qui seule est inattaquable au rationalisme, parce quelle embrasse non la raison seule de l'homme mais tout son être...» (там же).

28 Множество значений этого текста и его происхождение рассмотрены в статье И. И. Лапшина [Лапшин].

29 В ориг.: «Il prezzo che l'Inquisitore deve pagare alla missione cui si è votato è la corruzione politica del messaggio escatologico cristiano, ridotto ad arte di governo o economia cristiana (non fa differenza, da questo punto di vista, se si tratta di politica radicale che vuole portare la rivoluzione nel mondo, oppure di una politica compromissoria che mira all'ottundimento nella tranquillità sociale)» [«Ценой, которую приходится платить Инквизитору за миссию, служению которой он отдал себя, является политическое извращение христианского эсхатологического сообщения, сведенное к искусству правления или христианской экономики (согласно этой точке зрения, не имеет значения, идет ли речь о радикальной политике, которая хочет разжечь в мире революцию, или о политике компромиссов, направленной на отупение в общественном спокойствии)»] (перевод мой. - А. К.) [Zagrebelsky: 183].

30 Стихотворение «Мечта» было впервые опубликовано в журнале «Московский Наблюдатель» в 1835 г. (ч. I, с. 87); позднее в 10-м номере журнала «Маяк» за 1843 г. под названием «Запад и Восток» (см.: Хомяков А. С. Стихотворения и драмы. С. 555). 
31 Следует отметить еще одну точку соприкосновения двух авторов: Хомяков, как было установлено В. А. Кошелевым [Кошелев], был первооткрывателем особого жанра русской литературы - пасхального рассказа, а его оригинальным продолжателем стал Достоевский [Захаров, 1994], [Тамаев].

32 «Славянофилы - барская затея» (см. подготовительные материалы к роману «Бесы» - Д30; 11:64, 66).

33 О происхождении Достоевского см.: [Сараскина: 20-61].

34 См.: [Bettiolo: 225].

\section{Список литературы}

1. Бадалян Д. А. А. С. Хомяков и Ф. М. Достоевский: к истории развития «идеи народности» в русской культуре XIX в. // Вестник Санкт-Петербургского университета. Серия 2. История, языкознание, литературоведение. - 1999. - Вып. 4 (№ 23). - С. 108-111.

2. Библиотека Ф. М. Достоевского: опыт реконструкции. Научное описание. - СПб.: Наука, 2005. - 338 с.

3. Викторович В. А. «Выяснение» славянофильства: от Хомякова к Достоевскому // А. С. Хомяков - мыслитель, поэт, публицист: в 2 т.: сб. ст. по материалам междунар. науч. конф., состоявшейся 14-17 апреля 2004 г. в г. Москве в Литературном ин-те им. А. М. Горького / ред. Б. Н. Тарасов. - М.: Языки славянской культуры, 2007. - Т. 1. - С. 137-152.

4. Гроссман Л. П. Семинарий по Достоевскому: материалы, библиография и комментарии. - М.; Пг.: Государственное изд-во, 1922. - 120 с.

5. Грыжанкова М. Ю. Философская концепция «симфонии полногласия славянского и русского языка» А. С. Хомякова // Социальные и гуманитарные исследования: традиции и реальности. - Саранск: Мордовский государственный университет им. Н. П. Огарева, 2010. Вып. 12. - С. 49-52.

6. Егоров Б. Ф. Комментарии // Хомяков А. С. О старом и новом. Статьи и очерки. - М.: Современник, 1988. - С. 415-449.

7. Житкова Л. Н. Эстетика славянофилов // Достоевский: эстетика и поэтика: словарь-справочник / сост. Г. К. Щенников, А. А. Алексеев; науч. ред. Г. К. Щенников; ЧелГУ. - Челябинск: Металл, 1997. - С. 59 [Электронный ресурc]. — URL: https://www.fedordostoevsky.ru/research/ aesthetics-poetics/060/ (04.01.2019).

8. Захаров В.Н. Пасхальный рассказ как жанр русской литературы // Проблемы исторической поэтики. - 1994. - Вып. 3. - С. 249-261 [Электронный ресурс]. - URL: http://poetica.pro/journal/article. php?id=2403 (06.01.2019). DOI: 10.15393/j9.art.1994.2403

9. Захаров В. Н. Почвенничество в русской литературе: метафора как идеологема // Проблемы исторической поэтики. - 2012. - Вып. 10. C. 14-24 [Электронный pecypc]. - URL: http://poetica.pro/files/redaktor_pdf/1457946697.pdf (26.12.2018). DOI: 10.15393/j9.art.2012.335 (a)

10. Захаров В. Н. Заглавная буква в «Бесах», или почему нельзя править 
Достоевского // Достоевский Ф. М. Полн. собр. соч.: Канонические тексты. - Петрозаводск: Изд-во ПетрГУ, 2012. - Т. 9. - С. 661-676. (b)

11. Захаров В. Н. Вопрос о А. С. Хомякове // Захаров В. Н. Имя автора Достоевский. Очерк творчества. - М.: Индрик, 2013. - С. 231-247.

12. Кошелев В. А. «Светлое Воскресенье» А. С. Хомякова как вольное переложение «Рождественской песни в прозе» Ч. Диккенса // Москва. 1991. — № 4. - С. 81-84.

13. Кошелев В. А., Серебренников Н. В., Чернов А. В. Примечания // Хомяков А. С. Сочинения: в 2 т. - М.: Московский философский фонд; Медиум, 1994. - Т. 1: Работы по историософии / вступ. ст., сост. и подгот. текста В. А. Кошелева. - С. 534-589.

14. Лапшин И. И. Как сложилась легенда о Великом инквизиторе // О Достоевском: сб. ст. / под ред. А. Л. Бема. - Прага, 1929. - С. 125-139.

15. Новикова Е. Г. «Западные славяне» в «Дневнике писателя» Ф. М. Достоевского периода русско-турецкой войны 1877-1878 гг. // Имагология и компаративистика. - 2016. - № 1 (5). - С. 44-51.

16. Осповат А. Л. Достоевский и раннее славянофильство (1840-е годы) // Достоевский. Материалы и исследования. - Л.: Наука, 1976. - Вып. 2. C. $175-181$.

17. Сараскина Л. И. Достоевский. - М.: Молодая гвардия, 2013. - 825 с.

18. Сафонова А. В., Халикова Н. В. Образность (метафоричность) как средство семантической целостности сложного синтаксического целого в философско-публицистическом творчестве А. С. Хомякова (на примере статьи «Аристотель и всемирная выставка») // Рациональное и эмоциональное в русском языке: сб. тр. Международной научной конференции 20-21 ноября 2015 г. - М., 2015. - С. 190-195.

19. Сохряков Ю. И. Творчество Ф. М. Достоевского и русская проза ХХ века. - М.: ИМЛИ РАН, 2002. — 240 с.

20. Тамаев П. М. Пасхальная тема в творчестве А. С. Хомякова // Антикризисный потенциал. Традиции и проблемы имяславия. - Иваново; Шуя: ШГПУ, 2009. - С. 200-211.

21. Тарасова Н. А. «Дневник писателя» Ф. М. Достоевского (1876-1877): Критика текста. - М.: Квадрига; МБА, 2011. - 392 с.

22. Цыплаков Д. А., Желябовский Д. С. Социокультурные истоки историософии А. С. Хомякова // Идеи и идеалы. - 2010. - № 1 (3). T. 2. - C. 61-68.

23. Bettiolo P. Gesù il Vivente. Appunti sul Cristo di Dostoevskij // I volti moderni di Gesù. Arte, filosofia, storia / a cura di I. Adinolfi e Giuseppe Goisis. - Macerata: Quodlibet, 2013. - Pp. 201-229.

24. Cavazza A. «La Chiesa è una» di A. S. Chomjakov / edizione documentario-interpretativa. - Bologna: Il Mulino, 2007. - 366 p.

25. Supino V. I soggiorni di Dostoevskij in Europa e la loro influenza sulla sua opera. - Firenze: LoGisma, 2017. - 136 p.

26. Walicki A. Un'utopia conservatrice / tr. it. di M. Colucci. - Torino: Einaudi, 1973. - $604 \mathrm{p}$.

27. Zagrebelsky G. Liberi servi. Il Grande Inquisitore e l'enigma del potere. Torino: Einaudi, 2015. - 292 p. 
Antonella Cavazza

The University of Urbino Carlo Bo (Urbino, Italy)

antonella.cavazza@uniurb.it

\section{F. M. Dostoevsky and A. S. Khomyakov: Comparison at a Distance}

Abstract. The article is aimed at finding the meeting points between the world view of F. M. Dostoevsky and the philosophico-historical heritage of A. S. Khomyakov. Dostoevsky's texts contain a lot of direct and indirect references at the works of the mastermind of Slavophilism; the writer was acquainted with his philosophico-historical and theological writings as well as the poems. For instance, the article makes an analysis and comparison of two closely related questions in social and political essays of Dostoevsky and Khomyakov: the focus on Russian culture compared with the European one and contrasting Orthodoxy with Catholicism. Proceeding from two core themes of Dostoevsky essays, namely, the identification of Russian civilization against the European one and the criticism of Catholicism, the given research taking into consideration existing significant similarities with Khomyakov's works seeks to specify some terms and stylistic techniques through the use of which these ideas become more accurate in Dostoevsky's essays, particularly in "A Writer's Diary".

Keywords: soil, national spirit, culture, enlightenment, Orthodoxy, Catholicism, Oriental question, Slavic question

About the author: Cavazza Antonella - PhD, Associate Professor of Slavic Studies, The University of Urbino Carlo Bo (Piazza Rinascimento 7, Urbino, 61029, Italy).

Received: February 15, 2019

Date of publication: October 18, 2019

For citation: Cavazza A. F. M. Dostoevsky and A. S. Khomyakov: Comparison at a Distance. In: Problemy istoricheskoy poetiki [The Problems of Historical Poetics], 2019, vol. 17, no. 4, pp. 123-148. DOI: 10.15393/j9.art.2019.6282 (In Russ.)

\section{References}

1. Badalyan D. A. A. S. Khomyakov and F. M. Dostoevsky: On the History of the Genesis of the "Idea of National Spirit" in Russian Culture of the 19th Century. In: Vestnik Sankt-Peterburgskogo universiteta. Seriya 2. Istoriya, yazykoznanie, literaturovedenie [Vestnik of Saint Petersburg University. Series 2. History, Linguistics, Literary Studies], 1999, issue 4, no. 23, pp. 108-111. (In Russ.)

2. Biblioteka F. M. Dostoevskogo: opyt rekonstruktsii. Nauchnoe opisanie [F. M. Dostoevsky's Library: The Experiment of Reconstruction. Scientific Description]. St. Petersburg, Nauka Publ., 2005. 338 p. (In Russ.) 
3. Viktorovich V. A. The "Clarification" of Slavophilism: from Khomyakov to Dostoevsky. In: S. Khomyakov - myslitel', poet, publitsist: $v 2$ tomakh [S. Khomyakov as a Thinker, Poet and Publicist: in 2 Vols]. Moscow, Yazyki slavyanskoy kul'tury Publ., 2007, vol. 1, pp. 137-152. (In Russ.)

4. Grossman L. P. Seminariy po Dostoevskomu: materialy, bibliografiya $i$ kommentarii [A Colloquium on Dostoevsky: Materials, Bibliography and Comments]. Moscow, Petrograd, Gosudarstvennoe izdatel'stvo Publ., 1922. 120 p. (In Russ.)

5. Gryzhankova M. Yu. A Philosophical Concept of the "Symphony of Pleophony of the Slavic and Russian Languages" A. S. Khomyakova. In: Sotsial'nye i gumanitarnye issledovaniya: traditsii i real'nosti [Social and Humanitarian Researches: Traditions and Realities]. Saransk, N. P. Ogarev Mordovia State University Publ., 2010, issue 12, pp. 49-52. (In Russ.)

6. Egorov B. F. Commentaries. In: Khomyakov A. S. O starom i novom. Stat'i $i$ ocherki [Khomyakov A. S. About the Old and the New: Articles and Essays]. Moscow, Sovremennik Publ., 1988, pp. 415-449. (In Russ.)

7. Zhitkova L. N. The Aesthetics of the Slavophiles. In: Dostoevskiy: estetika i poetika: slovar'-spravochnik [Dostoevsky: Aesthetics and Poetics. Dictionary and Reference Book]. Chelyabinsk, Metall Publ., 1997, p. 59. Available at: https://www.fedordostoevsky.ru/research/aesthetics-poetics/060/ (accessed on January 4, 2019). (In Russ.)

8. Zakharov V. N. An Easter Story as a Russian Literary Genre. In: Problemy istoricheskoy poetiki [The Problems of Historical Poetics], 1994, issue 3, pp. 249-261. Available at: http://poetica.pro/journal/article.php?id=2403 (accessed on January 6, 2019). DOI: 10.15393/j9.art.1994.2403 (In Russ.)

9. Zakharov V. N. The Concept of the Soil in Russian Literature: A Metaphor as an Ideologeme. In: Problemy istoricheskoy poetiki [The Problems of Historical Poetics], 2012, issue 10, pp. 14-24. Available at: http://poetica.pro/files/ redaktor_pdf/1457946697.pdf (accessed on December 26, 2018). DOI: 10.15393/ j9.art.2012.335 (In Russ.) (a)

10. Zakharov V. N. The Capital Letter in "The Possessed", or Why is it Impossible to Edit Dostoevsky's Writings. In: Dostoevskiy F. M. Polnoe sobranie sochineniy: Kanonicheskie teksty [Dostoevsky F. M. The Complete Works: Canonical Texts]. Petrozavodsk, Petrozavodsk State University Publ., 2012, vol. 9, pp. 661-676. (In Russ.) (b)

11. Zakharov V. N. The Question About A. S. Khomyakov. In: Zakharov V. N. Imya avtora - Dostoevskiy. Ocherk tvorchestva [Zakharov V. N. The Author's Name is Dostoevsky. An Essay on the Creative Work]. Moscow, Indrik Publ., 2013, pp. 231-247. (In Russ.)

12. Koshelev V. A. The "Easter Sunday" by A. S. Khomyakov as a Loose Adaptation of "A Christmas Song in Prose" by Ch. Dickens. In: Moskva, 1991, no. 4, pp. 81-84. (In Russ.)

13. Koshelev V. A., Serebrennikov N. V., Chernov A. V. Notes. In: Khomyakov A. S. Sochineniya: 2 tomakh [Khomyakov A. S. Works: in 2 Vols]. Moscow, Moskovskiy filosofskiy fond Publ., Medium Publ., 1994, vol. 1, pp. 534-589. (In Russ.) 
14. Lapshin I. I. How did the Legend of The Grand Inquisitor Appear? In: O Dostoevskom: sbornik statey [About Dostoevsky: Collection of Articles]. Prague, 1929, pp. 125-139. (In Russ.)

15. Novikova E. G. The "Western Slavs" in "A Writer's Diary" by F. M. Dostoevsky in the Time of the Russian-Turkish War of 1877-1878. In: Imagologiya i komparativistika [The Imagology and Comparative Studies], 2016, no. 1 (5), pp. 44-51. (In Russ.)

16. Ospovat A. L. Dostoevsky and the Early Slavophilism (1840ies). In: Dostoevskiy. Materialy $i$ issledovaniya [Dostoevsky. Materials and Researches]. Leningrad, Nauka Publ., 1976, issue 2, pp. 175-181. (In Russ.)

17. Saraskina L. I. Dostoevsky. Moscow, Molodaya gvardiya Publ., 2013. 825 p. (In Russ.)

18. Safonova A. V., Khalikova N. V. Figurativeness (Metaphoricity) as a Means of Semantic Integrity of a Complex Syntactic Overall in the Philosophical and Journalistic Works of A. S. Khomyakov (by the Example of the Article "Aristotle and the World Exhibition"). In: Ratsional'noe i emotsional'noe $v$ russkom yazyke: sbornik trudov Mezhdunarodnoy nauchnoy konferentsii [The Rational and the Emotional in the Russian Language: Proceedings of the International Scientific Conference]. Moscow, 2015, pp. 190-195. (In Russ.)

19. Sokhryakov Yu. I. Tvorchestvo F. M. Dostoevskogo i russkaya proza XX veka [The Works of F. M. Dostoevsky and Russian Prose of the 20th Century]. Moscow, the Gorky Institute of World Literature of the Russian Academy of Sciences Publ., 2002. 240 p. (In Russ.)

20.Tamaev P. M. The Easter Theme in the Works of A. S. Khomyakov. In: Antikrizisnyy potentsial. Traditsii i problemy imyaslaviya [Anti-Crisis Potential. The Traditions and the Problems of Onomatodoxy]. Ivanovo, Shuya, Shuya State Pedagogical University Publ., 2009, pp. 200-211. (In Russ.)

21. Tarasova N. A. «Dnevnik pisatelya» F. M. Dostoevskogo (1876-1877): Kritika teksta [“A Writer's Diary" by F. M. Dostoevsky (1876-1877): Textual Criticism]. Moscow, Kvadriga Publ., MBA Publ., 2011. 392 p. (In Russ.)

22. Tsyplakov D. A., Zhelyabovskiy D. S. The Sociocultural Origins of Historiosophy of A. S. Khomyakov. In: Idei i idealy [Ideas and Ideals], 2010, no. 1 (3), vol. 2, pp. 61-68. (In Russ.)

23. Bettiolo P. Gesù il Vivente. Appunti sul Cristo di Dostoevskij [Jesus Living. Notes on Christ of Dostoevsky]. In: I volti moderni di Gesù. Arte, filosofia, storia [Modern Faces of Jesus. Art, Philosophy, History]. Macerata, Quodlibet Publ., 2013, pp. 201-229. (In Italian)

24. Cavazza A. "La Chiesa è una" di A. S. Chomjakov ["The Church is Unique" by A. S. Khomyakov]. Bologna, Il Mulino Publ., 2007. 366 p. (In Italian)

25. Supino V. I soggiorni di Dostoevskij in Europa e la loro influenza sulla sua opera [Dostoevsky's Stay in Europe and its Influence on His Work]. Firenze, LoGisma Publ., 2017. 136 p. (In Italian)

26. Walicki A. Un'utopia conservatrice [A Conservative Utopia]. Torino, Einaudi Publ., 1973. 604 p. (In Italian)

27. Zagrebelsky G. Liberi servi. Il Grande Inquisitore e l'enigma del potere [Free Servants. The Grand Inquisitor and the Enigma of Power]. Torino, Einaudi Publ., 2015. 292 p. (In Italian) 